Situs Jurnal : $\underline{\text { http://ejurnal.stiepancasetia.ac.id/index.php/jieb }}$

Jilid 4 Nomor 2 Juli 2018

Hal $247-254$

\title{
PENGARUH KINERJA KEUANGAN TERHADAP AKUNTABILITAS KINERJA INSTANSI PADA DINAS ENERGI DAN SUMBER DAYA MINERAL PROVINSI KALIMANTAN SELATAN
}

\section{Siti Aisyah*}

Abstract: This study aims to provide information to the public regarding the presentation of the goverment's performance in achieving accountability. To determine the performance of Energy and Mineral Resources Department in South Borneo Province.District goverments using financial ratios budget especially the ratio of local independence, the ratio of financial dependence, the ratio of effectiveness, efficiency ratio, the ratio of the ratio of the activity, the ratio of growth. Financial ratio analysis on revenue and expenditure budget for the 2011-2017. The analytical tool used using classic assumption test and regression analysis. The results showed that the variables X1 and X2 have unsignificant partial to Y. In simultaneous F test $\mathrm{X} 1$ and $\mathrm{X} 2$ have unsignificant partial to $\mathrm{Y}$

Keywords: financial performance, government's accountability, Energy and Mineral Resources Department

Abstrak: Penelitian ini bertujuan untuk mengetahui dan memberikan informasi kepada masyarakat mengenai penyajian laporan keuangan dan kinerja pemerintah daerah dalam mewujudkan pertanggungjawaban. Untuk mengetahui kinerja keuangan di Dinas Energi dan Sumber Daya Mineral Provinsi Kalimantan Selatan dengan menggunakan rasio aktivitas. Alat analisis yang digunakan menggunakan uji asumsi klasik dan analisis regresi. Hasil yang didapat menujukkan pada uji t menunjukkan bahwa variabel X1 dan X2 tidak berpengaruh signifikan terhadap variable $\mathrm{Y}$. Pada uji $\mathrm{F}$ secara simultan variable $\mathrm{X} 1$ dan $\mathrm{X} 2$ tidak berpengaruh signifikan terhadap variable $\mathrm{Y}$.

Kata kunci : kinerja keuangan, akuntabilitas instansi pemerintah, Dinas Energi dan Sumber Daya Mineral

\section{Latar Belakang}

Dalam rangka mewujudkan masyarakat Indonesia yang adil dan makmur, maka pelaksanaan pembangunan ekonomi haruslah lebih memperhatikan keserasian, keselarasan dan kesinambungan unsure-unsur pemerataan pembangunan. Perkembangan pembangunan suatu daerah sangat ditentukan oleh sumber pendapatan daerah terutama untuk menutupi pembiayaan pemerintah daerah dalam melaksanakan tugasnya. Untuk itu diperlukan kemampuan pemerintah daerah dalam mengatur perokonomian daerahnya untuk membiayai seluruh kebutuhan dana pembangunan yang diperlukan.

Pengukuran kinerja keuangan untuk kepentingan public dapat dijadikan evaluasi dan pemulihan kinerja dengan pembanding skema kerja dan pelaksanaannya. Selain itu dapat juga dijadikan sebagai tolak ukur untuk meningkatkan kinerja khususnya keuangan pemerintah di daerah pada periode berikutnya. Adanya otonomi daerah tersebut mengakibatkan adanya desentralisasi system pemerintahan, pembangunan dan pelayanan masyarakat wajib 
melaporkan pertanggungjawaban keuangan untuk dinilai apakah instansi pemerintah berhasil menjalankan tugas daerah dengan baik atau tidak. Analisa kinerja keuangan adalah suatu proses penilaian mengenai tingkat kemajuan pencapaian pelaksanaan pekerjjaan/kegiatan instansi tersebut dalam bidang keuangan dalam kurun waktu tertentu.

Sejalan dengan hal tersebut penerapan anggaran berbasis kinerja diatur dalam Permendagri Nomor 13 Tahun 2006 dan diubah lagi dengan Permendagri Nomor 59 Tahun 2007 tentang pedoman pengelolaan keuangan daerah. Dalam peraturan ini disebutkan tentang Penyusunan Rencana Kerja dan Anggaran Satuan Kerja Perangkat Daerah (RKA-SKPD). Adanya RKA-SKPD ini berarti telah terpenuhinya kebutuhan tentang anggaran berbasis kinerja dan akuntabilitas. Dimana anggaran berbasis kinerja menuntut adanya output optimal atau pengeluaran yang dialokasikan sehingga setiap pengeluaran harus berorientasi atau bersifat ekonomi, efisien dan efektif.

Anggaran berbasis kinerja (Performance Based Budgeting) merupakan sistem penganggaran yang berorientasi pada output organisasi dan berkaitan sangat erat dengan visi, misi, dan rencana strategis organisasi. Anggaran yang tidak efektif dan tidak berorientasi pada kinerja akan dapat menggagalkan perencanaan yang telah disusun. Pengukuran kinerja secara berkelanjutan akan memberikan umpan balik, sehingga upaya perbaikan secara terus menerus akan mencapai keberhasilan di masa mendatang (Indra Bastian, 2006). Mardiasmo (2002) menyatakan bahwa pendekatan penyusunan anggaran berbasis kinerja disusun untuk mengatasi berbagai kelemahan yang terdapat dalam anggaran tradisional, khususnya kelemahan yang disebabkan oleh tidak adanya tolak ukur yang dapat digunakan untuk mengukur kinerja dalam pencapaian tujuan dan sasaran pelayanan publik. Anggaran dengan pendekatan kinerja sangat menekankan konsep value for money dan pengawasan atas kinerja output.

Anggaran yang tidak efektif dan tidak berorientasi pada kinerja akan dapat menggagalkan perencanaan yang telah disusun. Pengukuran kinerja secara berkelanjutan akan memberikan umpan balik, sehingga upaya perbaikan secara terus menerus akan mencapai keberhasilan dimasa mendatang (Bastian, 2009:275).

Tujuan penganggaran berbasis kinerja adalah untuk menunjukan keterkaitan antara pendanaan dan prestasi kinerja yang akan dicapai, meningkatkan efisiensi dan transparansi dalam penganggaran, meningkatkan fleksibilitas dan akuntabilitas unit dalam melaksanakan tugas dan pengelolaan anggaran.

Anggaran pada instansi pemerintahan selain bertugas sebagai alat perencanaan dan alat pengendalian, juga berfungsi sebagai instrument akuntabilitas public atas pengelolaan dana public dan pelaksanaan program-program yang dibiayai dengan uang public. Sebagai alat akuntabilitas public, penggunaan anggaran harus dapat dipertanggungjawabkan dengan menggunakan hasil dari dibelanjakannya dana public tersebut. Sehingga pada akhirnya dapat diperoleh gambaran mengenai kinerja instansi pemerintah. Dalam rangka untuk meningkatkan kinerja instansi pemerintah dikeluarkan regulasi yang mengatur mengenai perubahan pengelolaan keuangan daerah utuk dapat lebih meningkatkan pelaksanaan pemerintahan yang lebih berdaya guna, bersih dan bertanggung jawab, pemerintah mengeluarkan instruksi Presiden Nomor 7 Tahun 1999 (Inpres7:1999) tentang Akuntabilitas Kinerja Instansi Pemerintah.

Berdasarkan latar belakang permasalahan diatas, maka rumusan masalah yang akan di ambil dalam penelitian ini yaitu:

1. Apakah kinerja keuangan secara simultan berpengaruh signifikan terhadap akuntabilitas kinerja instansi pada Dinas Energi dan Sumber Daya Mineral Provinsi Kalimantan Selatan? 
2. Apakah kinerja keuangan berpengaruh signifikan secara parsial terhadap akuntabilitas kinerja instansi pada Dinas Energi dan Sumber Daya Mineral Provinsi Kalimantan Selatan?

3. Manakah diantara rasio kinerja keuangan yang berpengaruh dominan terhadap akuntabilitas kinerja instansi pada Dinas Energi dan Sumber Daya Mineral Provinsi Kalimantan Selatan?

\section{Kajian Literatur}

Peraturan Menteri Dalam Negeri Nomor 13 Tahun 2006 tentang Pedoman Pengelolaan Keuangan Daerah dinyatakan bahwa kinerja adalah keluaran/hasil dari kegiatan atau program yang akan atau telah dicapai sehubungan dengan penggunaan anggaran dengan kuantitas dan kualitas yang terukur. Kinerja merupakan gambaran mengenai tingkat pencapaian pelaksanaan suatu program organisasi dalam mewujudkan tujuan organisasi, pengeluaran hasil kerja organisasi, keputusan pelanggan, serta kontribusinya terhadap perkembangan ekonomi masyarakat (Suprapto, 2006).

Halim (2004:24) kinerja keuangan daerah atau kemampuan daerah merupakan salah satu ukuran yang dapat digunakan untuk melihat kemampuan daerah dalam menjalankan otonomi daerah.

Beberapa rasio keuangan yang dapat digunakan untuk kinerja keuangan daerah (Halim, 2007) yang meliputi:

1. Rasio Kemandirian Keuangan Daerah

Rasio kemandirian keuangan daerah atau rasio desentraslisasi fiskal menunjukkan kemampuan Pemerintah Daerah dalam membiayai sendiri kegiatan pemerintahan, pembangunan, dan pelayanan kepada masyarakat yang telah membayar pajak dan retribusi sebagai sumber pendapatan yang diperlukan daerah.

\section{Rasio Efektivitas Keuangan Daerah}

Rasio efektivitas menggambarkan kemampuan Pemerintah Daerah dalam merealisasikan APBD yang direncanakan dan dibandingkan dengan target yang ditetapkan berdasarkan potensi nyata daerah. Artinya, rasio ini merupakan hasil perbandingan (nisbah) antara APBD yang telah terealisasi dengan APBD yang telah ditargetkan sebelumnya (Halim 2007).

\section{Rasio Efisiensi Keuangan Daerah}

Rasio efisiensi adalah rasio yang menggambarkan perbandingan antara output dan input atau realisasi pengeluaran dengan realisasi penerimaan daerah. Semakin kecil rasio ini, maka semakin efisien, begitu pula sebaliknya. Pengukuran kinerja pemerintah daerah dapat diukur dengan menilai efisiensi atas pelayanan yang diberikan kepada masyarakat (Mahmudi, 2011).

4. Rasio Aktivitas (Keserasian Belanja Daerah)

Rasio aktivitas (Keserasian Belanja Daerah) adalah rasio keuangan daerah yang menggambarkan bagaimana Pemerintah Daerah memprioritaskan alokasi dananya pada belanja rutin dan belanja pembangunan secara optimal.

5. Rasio Pertumbuhan

Rasio pertumbuhan bermanfaat untuk mengatahui apakah pemerintah daerah dalam tahun anggaran bersangkutan atau selama beberapa periode anggaran, kinerja anggarannya mengalami pertumbuhan pendapatan atau belanja secara positif atau negative (Mahmudi 2010:138). Rasio ini mengukur seberapa besar kemampuan pemerintah daerah dalam 
mempertahankan dan meningkatkan keberhasilannya yang telah dicapai dari satu periode ke periode berikutnya.

\section{Rasio Keserasian}

Rasio Keserasian menggambarkan bagaimana pemerintah daerah memprioritaskan alokasi dananya pada Belanja Rutin dan Belanja Pembangunannya secara optimal. Semakin tinggi persentase dana yang dialokasikan untuk Belanja Rutin berarti persentase Belanja investasi (Belanja Pembangunan) yang digunakan untuk menyediakan sarana dan prasarana untuk meningkatkan efektifitas dan efisiensi kegiatan ekonomi masyarakat cenderung semakin kecil (Abdul Halim 2007:236).

\section{Metode Penelitian}

Pada penelitian ini menggunakan penelitian penjelasan (explanation reseach) dengan pendekatan kuantitatif, karena dalam penelitian ini metode yang digunakan adalah metode penjelasan (explanatory) yaitu menguji hipotesis-hipotesis berdasarkan teori yang telah dirumuskan sebelumnya dan kemudian data yang telah diperoleh hitung lebih lanjut melalui pendekatan kuantitatif (Sugiyono, 2009:6). Adapun populasi dalam penelitian ini adalah data kinerja keuangan dan data anggaran keuangan pada Dinas Sumber Daya Energi Dan Mineral Kota Banjarbaru pada periode 2011-2017.

Penelitian ini menggunakan dua variabel yaitu variabel bebas dan variabel terikat. Variabel terikat (Y) dalam penelitan ini adalah Akuntabilitas Kinerja Instansi. Sedangkan variabel bebas dalam penelitian ini adalah faktor-faktor fundamental berupa Rasio Aktivitas Belanja Rutin (X1) dan Rasio Aktivitas Belanja Modal (X2)

\section{Hasil Penelitian dan Pembahasan}

Dinas Pertambangan dan Energi Provinsi Kalimantan Selatan , pada awalnya dibentuk tahun 1989. Sejak otonomi daerah kedudukan Dinas Pertambangan dan Energi diatur berdasarkan Peraturan Daerah Provinsi Kalimantan Selatan Nomor 8 Tahun 2000 Tentang Pembentukan Susunan Organisasi dan tata Kerja Perangkat Daerah dan Sekretariat Dewan Perwakilan Daerah Provinsi Kalimantan Selatan serta Peraturan Gubernur Kalimantan Selatan Nomor 039 Tahun 2009 dengan tugas pokok adalah melaksanakan urusan disentralisasi dan dekonsentralisasi serta tugas pembantuan yang diberikan oleh pemerintah guna melakanakan tugas pokok tersebut.

Penelitian ini dilakukan melalui beberapa tahapan proses analisis data untuk mendapatkan informasi yang relevan. Serangkaian Hasil analisis pada penelitian ini dapat dijabarikan sebagai berikut:

1. Uji Multikolinearitas

Uji Multikolinieritas bertujuan untuk menguji apakah model regresi ditemukan adanya korelasi antar variabel bebas. Model regresi yang baik seharusnya tidak terjadi kolerasi diantara variabel independen. Deteksi terhadap ada tidaknya multikolinieritas, yaitu dapat diketahui dengan melihat pada nilai tolerance dan variance inflation factor (VIF). Nilai tolerance dan variance inflation factor (VIF) suatu model regresi yang dinyatakan bebas dari masalah multikolinearitas apabila mempunyai nilai tolerance memndekati 1 dan nilai VIF tidak lebih dari 10.

Berdasarkan hasil perhitungan Colinearity statistic's pada table 1 terlihat bahwa nilai tolerance mendekati 1 dan nilai VIF diatas menunjukkan kedua variabel bebas yang memiliki nilai VIF lebih dari 10. Jadi dapat disimpulkan bahwa hasil penelitian ini memiliki gejala multikolinearitas antar variabel bebas dalam model regresi. 
Tabel 1. Hasil Uji Multikolonieritas

\begin{tabular}{|c|c|c|c|}
\hline Model Summary & & & \\
\hline Model & R Square & $\begin{array}{l}\text { Adjusted R } \\
\text { Square }\end{array}$ & $\begin{array}{l}\text { Std. Error of the } \\
\text { Estimate }\end{array}$ \\
\hline
\end{tabular}

\begin{tabular}{rrrrr}
\hline 1 &, $677^{\mathrm{a}}$ & 0,458 & 0,187 & 4,57503 \\
\hline
\end{tabular}

a. Predictors: (Constant), X2, X1

b. Dependent Variable: Y

2. Uji Normalitas

Uji normalitas dilakukan untuk mengetahui apakah dalam model regresi nilai residual terdistribusi normal. Model regresi yang baik memiliki nilai residual yang terdistribusi normal. Uji normalitas dilakukan dengan uji Kolmogorov Smirnov. Data terdistribusi normal jika residualnya lebih besar dari 0,05. Hasil uji normalitas disajikan pada Gambar 1

\section{Normal P-P Plot of Regression Standardized Residual}

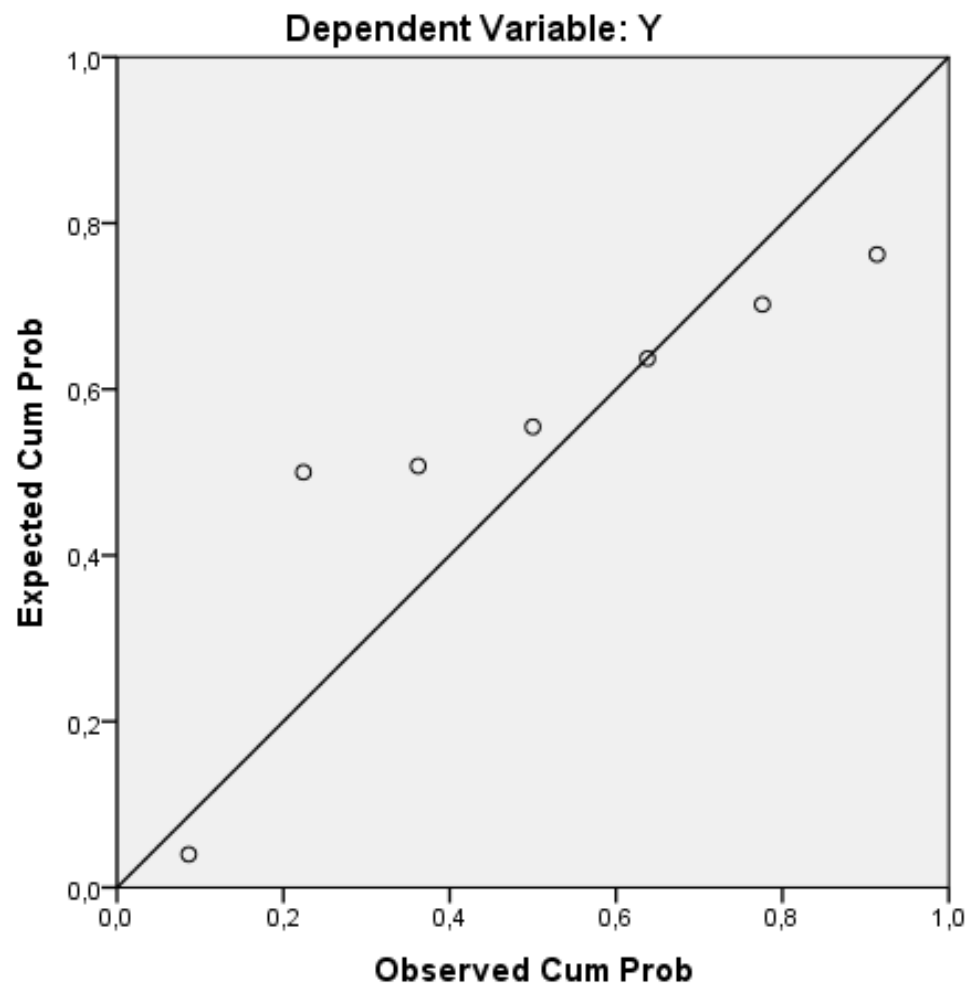

Gambar 1. Hasil Uji Normalitas

Berdasarkan Gambar 1, menunjukkan bahwa model regresi yang diperoleh berdistribusi normal, karena sebaran data berada disekitas garis diagonal.

3. Uji Heterokedastisitas

Uji heterokedastisitas bertujuan untuk menguji apakah dalam model regresi terjadi ketidaksamaan varian dari residual satu pengamatan ke pengamatan lainnya. Apabila koefisien korelasi dari masing-masing variabel independen ada yang signifikan pada tingkat kekeliruan 5\% (0,05) mengindikasikan adanya heterokedastisitas. Hasil uji heterokedastisitas disajikan pada Gambar 2 


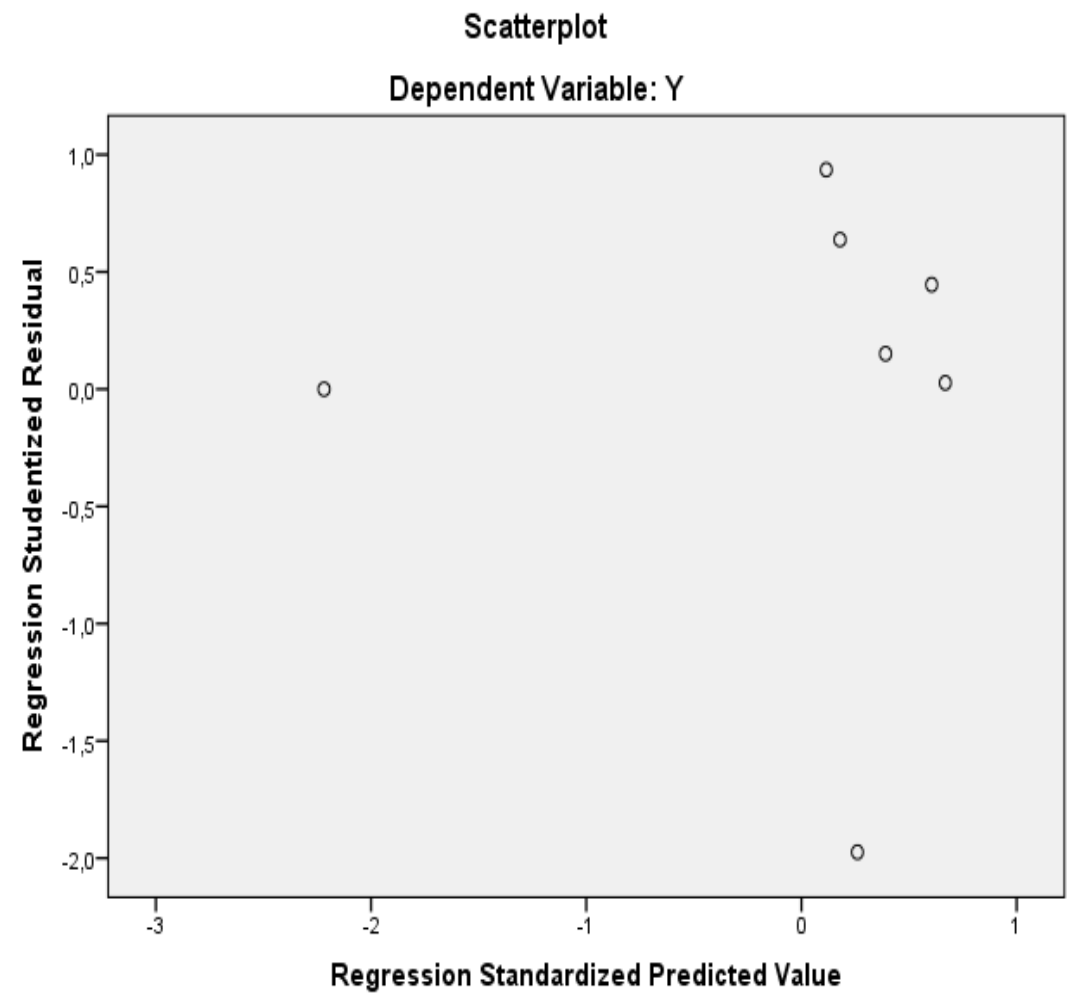

Gambar 2. Hasil Uji Heterokedastisitas

Terlihat grafik scalerplot diatas bahwa titik tidak menyebar secara acak baik diatas maupun dibawah angka 0 pada sumbu Y. Hal ini menyimpulkan bahwa terjadi heterokedastisitas model regresi. Maka data yang digunakan memenuhi syarat untuk dilakukan uji regresi berganda.

\section{Uji Autokorelasi}

Hasil uji Autokolerasi menggunakan Durbin Watson(DW) - Test dapat dilihat pada tabel 2.

Tabel 2. Uji Autokorelasi

\begin{tabular}{lccccc}
\hline \multicolumn{5}{c}{ Model Summary $^{\mathbf{b}}$} \\
\hline Model & $\mathrm{R}$ & $\mathrm{R}$ Square & $\begin{array}{c}\text { Adjusted R } \\
\text { Square }\end{array}$ & $\begin{array}{c}\text { Std. Error of the } \\
\text { Estimate }\end{array}$ & $\begin{array}{l}\text { Durbin- } \\
\text { Watson }\end{array}$ \\
\hline 1 &, $677^{\mathrm{a}}$ & 0,458 & 0,187 & 4,57503 & 2,698 \\
\hline \multicolumn{2}{l}{ a. Predictors: (Constant), X2, X1 } & & & \\
\hline \multicolumn{2}{l}{ b. Dependent Variable: $\mathrm{Y}$} & & & \\
\hline
\end{tabular}

Berdasarkan tabel diatas, diketahui bahwa nilai $\mathrm{d}=2$,698. Selanjutnya dari Tabel DW dengan $\mathrm{n}$ (jumlah observasi) $=7 \mathrm{k}$ (jumlah variabel bebas) $=2$, dan Alpha 0,01 diperoleh $\mathrm{dL}=0,4672$ dan $\mathrm{dU}=1,8964$ sehingga $(4-\mathrm{dL})=3,533$ dan $(4-\mathrm{dU})=2,104$. Dengan demikian nilai DW terletak antara dL dan dU, berarti tidak ada autokorelasi. 
5. Uji Hipotesis I: Uji t Secara Parsial

Melalui pengujian ini akan dapat diketahui apakah variabel yang terdiri dari Rasio Belanja Rutin APBD (X1) dan Rasio Belanja Pembangunan (X2) berpengaruh secara parsial terhadap Akuntabilitas Kinerja Instansi (Y) pada Dinas Energi dan Sumber Daya Mineral Provinsi Kalsel berdasarkan nilai signifikansi hasil output SPSS. Jika nilai Sig. $<0,05$ maka variabel bebas berpengaruh signifikan terhadap variabel terikat. Jika nilai Sig. > 0,05 maka variabel bebas tidak berpengaruh signifikan terhadap variabel terikat. Hasil uji t pada penelitian kali ini dapat dilihat pada tabel 3 .

Tabel 3. Hasil Uji t

\begin{tabular}{|c|c|c|c|c|c|c|}
\hline \multicolumn{7}{|c|}{ Coefficients $^{\mathrm{a}}$} \\
\hline & \multirow[t]{2}{*}{ Model } & \multicolumn{2}{|c|}{$\begin{array}{l}\text { Unstandardized } \\
\text { Coefficients }\end{array}$} & \multirow{2}{*}{$\begin{array}{c}\text { Standardized } \\
\text { Coefficients } \\
\text { Beta }\end{array}$} & \multirow[t]{2}{*}{$\mathrm{t}$} & \multirow[t]{2}{*}{ Sig. } \\
\hline & & B & $\begin{array}{l}\text { 1ents } \\
\text { Std. Error }\end{array}$ & & & \\
\hline \multirow[t]{3}{*}{1} & (Constant) & $-2212,98$ & 1268,635 & & $-1,744$ & 0,156 \\
\hline & $\mathrm{X} 1$ & 23,114 & 12,699 & 20,478 & 1,82 & 0,143 \\
\hline & $\mathrm{X} 2$ & 22,956 & 12,678 & 20,372 & 1,811 & 0,144 \\
\hline
\end{tabular}

a. Dependent Variable: $\mathrm{Y}$

Pengujian statistik uji t pada tabel 3 pada dasarnya menunjukan seberapa jauh pengaruh satu variabel independen secara parsial dalam menerangkan variasi variabel dependen. Hasil pengujian dari uji t dapat dijelaskan sebagai berikut :

a. Konstanta $(\alpha)$

Persamaan regresi linier berganda tersebut memiliki nilai positif pada konstanta $-2212,98$ yang menyatakan bahwa apabila Rasio Belanja Rutin APBD (X1) dan Rasio Belanja Pembangunan (X2) bernilai 0, maka Akuntabilitas Kinerja Instansi (Y) akan bernilai negatif.

b. Pengujian Hipotesis Pertama (Ha1)

Nilai signifikansi hitung variabel X1 sebesar 0,143 yang berada di atas 0,05. Dilihat dari tingkat signifikansi $>0,05$ dengan demikian Ha1 ditolak. Jadi bisa diasumsikan dengan ketiadaanya variable lainnya maka seandainya variabel Rasio Belanja Rutin APBD mengalami peningkatan maka Akuntabilitas Kinerja Instansi akan menurun artinya jika Rasio Belanja Rutin APBD lebih ditekankan maka akan menyebabkan Akuntabilitas Kinerja Instansi menurun.

c. Pengujian Hipotesis Kedua (Ha2)

Nilai signifikansi hitung variabel X2 sebesar 0.144 yang berada diatas $0,05(5 \%)$ dengan demikian Ha2 ditolak. Dengan ini bisa diasumsikan jika dengan ketiadaan variable lainya maka jika Rasio Belanja Pembangunan (X2) naik maka Kinerja akan meningkat, hal ini menunjukkan Rasio Belanja Pembangunan (X2) berpengaruh negatif terhadap Akuntabilitas Kinerja Instansi.

6. Uji Hipotesis II: Uji F Secara Simultan

Tabel 4. Hasil Uji F

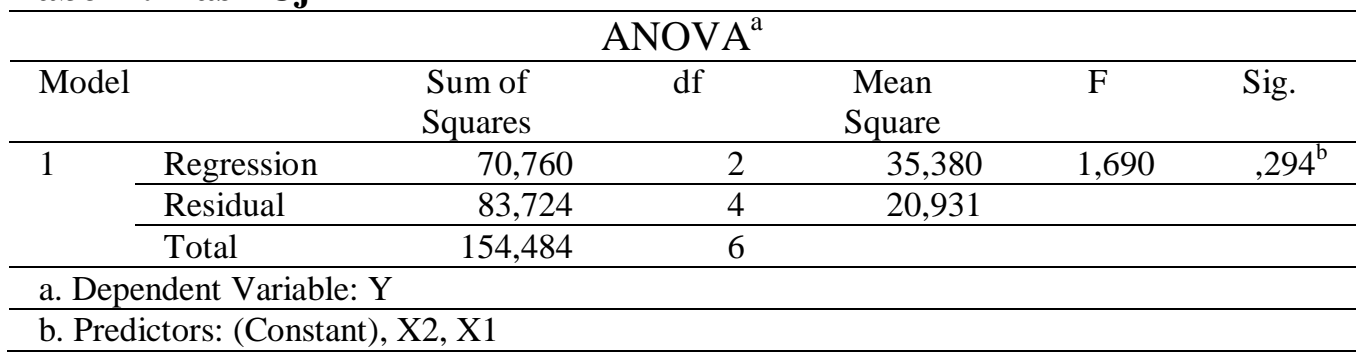


Berdasarkan perhitungan Sig.F-hitung diperoleh hasil sebesar 0,294 $>\alpha 0,05$. Nilai probabilitas signifikan pengujian tersebut lebih besar dari $\alpha(0,05)$ maka dapat simpulkan bahwa tidak terdapat pengaruh yang signifikan antara Rasio Belanja Rutin (X1) dan Rasio Belanja Pembangunan (X2) secara simultan terhadap Akuntabilitas kinerja instansi.

\section{Kesimpulan}

Berdasarkan hasil penelitian dan pembahasan pada bab-bab sebelumnya maka kesimpulan yang dapat diambil dari penelitian ini adalah :

1. Variabel Rasio Belanja Rutin terhadap APBD (X1), dan Rasio Belanja Pembangunan terhadap APBD (X2) secara parsial tidak berpengaruh signifikan terhadap Akuntabilitas kinerja instansi (Y) pada Dinas Energi dan Sumber Daya Mineral Provinsi Kalimantan Selatan.

2. Variabel Rasio Belanja Rutin terhadap APBD (X1), dan Rasio Belanja Pembangunan terhadap APBD (X2) secara simultan tidak berpengaruh signifikan terhadap Akuntabilitas kinerja instansi (Y) pada Dinas Energi dan Sumber Daya Mineral Provinsi Kalimantan Selatan.

3. Diantara kedua variabel bebas yaitu variable Rasio Belanja Rutin terhadap APBD (X1), dan Rasio Belanja Pembangunan terhadap APBD (X2), keduanya tidak memiliki pengaruh yang dominan terhadap Akuntabilitas kinerja instansi (Y) pada Dinas Energi dan Sumber Daya Mineral Provinsi Kalimantan Selatan.

\section{DAFTAR PUSTAKA}

Bastian Indra dan Gatot S, 2003, Sistem Akuntansi Sektor Publik- Konsep untuk Pemerintah Daerah, Salemba Empat, Jakarta.

Bastian Indra, 2006,P Akuntansi Sektor Publik, Suatu Pengantar, Erlangga

Halim Abdul , 2007. Akuntansi Sektor Publik : Akuntansi Keuangan Daerah, Edisi 3, Salemba Empat, Jakarta.

Halim Abdul, et.al. 2012. Teori, Konsep, dan Aplikasi Akuntansi Sektor Publik, Salemba Empat, Jakarta.

Harahap Sofyan Sahri, 2006. Analitis Kritis atas Laporan Keuangan, Raja Grafindo, Jakarta

Ikatan Akuntan Indonesia, 2009, Standar Akuntansi Keuangan Indonesia, Salemba Empat, Jakarta

Kasmir, 2008, Analisis Laporan Keuangan, PT Raja Grafindo Persada, Jakarta

Munawir, S, 2004, Analisa Laporan Keuangan, Edisi IV, Liberty, Yogjakarta.

Mardiasmo, 2004, Akuntansi Sektor Publik, CV. Andi Offset, Yogjakarta

Sawir, Agnes, 2005. Analisis Kinerja Keuangan dan Perencanaan Keuangan Perusahaan, Gramedia Pustaka Utama, Jakarta.

Peraturan Pemerintah No. 24 tahun 2005 tentang STANDAR AKUNTANSI PEMERINTAHAN, Komite Standar Akuntansi Pemerintahan, Salemba Empat

Peraturan Pemerintah No. 71 tahun 2010 tentang STANDAR AKUNTANSI PEMERINTAHAN, Komite Standar Akuntansi Pemerintahan, Salemba Empat 